DOI: $10.2478 / \mathrm{v} 10014-008-0020-7$

Agrovoc descriptors: arachis hypogaea; ferralsols; benomyl; vesicular arbuscular mycorrhizae; phosphorus; growth rate; fungicides; roots

Agris category code: P34; F61

COBISS Code 1.01

\title{
Indigenous arbuscular mycorrhiza is more important for early growth period of groundnut (Arachis hypogea L.) for $P$ influx in an Oxisol
}

\author{
Amitava RAKSHIT ${ }^{1}$ and P.B.S BHADORIA ${ }^{2}$
}

Received: July 29, 2007; accepted: June 8, 2008.

Prispelo 29. julija 2007; sprejeto 8. junija 2008.

\begin{abstract}
The contribution of indigenous arbuscular mycorrhiza (AM) on phosphorus (P) uptake by groundnut was examined in a low $P$ field soil. The fungicide benomyl was applied to eradicate mycorrhizal infection. The treatments consisted of three $P$ levels viz. 0,50 and $400 \mathrm{mg} \mathrm{P} \mathrm{kg}^{-1}$ soil, with and without benomyl application. Groundnut as test crop was sown two weeks after the application of benomyl and was harvested four times covering the whole growth period. At each harvest, the shoot yield, shoot $\mathrm{P}$ concentration, root length, soil solution $\mathrm{P}\left(\mathrm{C}_{\mathrm{Li}}\right)$ and per cent root infection by AM was determined for benomyl treated and untreated soil at all $P$ levels. Benomyl showed no effect on soil solution $\mathrm{P}$ concentration. When $\mathrm{P}$ was limiting, application of benomyl did reduce early groundnut growth by $40-50 \%$ at $\mathrm{P}-0$, and by $25-30 \%$ at $\mathrm{P}-50$. At high $P$ supply $(P-400)$, benomyl had little or no effect on dry matter production. Thus, indicate that the effect of benomyl on plant growth was by its influence on $\mathrm{P}$ uptake from soil. Phosphorus supply affected percentage of root infected by AM which was $40 \%$ of the roots at P-0, and decreased to around $30 \%$ and $10 \%$ at $\mathrm{P}-50$ and $\mathrm{P}-400$. In the early growing season, the $\mathrm{P}$ influx of maize was dependent on $P$ in soil solution and the effect of $A M$ was rather large. At high $P$ supply, the contribution of AM to $P$ influx showed a decrease. Without or low AM infection and at low $\mathrm{P}$ level, the $\mathrm{P}$ influx was $62 \%$ of that with $\mathrm{AM}$. During early growth period groundnut showed a similar behaviour as maize at middle growth stage and without AM reduction of $P$ influx, which was to an extent of $67 \%$. In absolute terms AM is more important at maximum growth in the early growth season for groundnut. It is evident from the present investigation that AM may make an significant contribution by about $35 \%$ to the $P$ nutrition of groundnut, but other factors, like P solubilization by root exudates, may be even more important.
\end{abstract}

Key words: Oxisol, benomyl, arbuscular mycorrhiza, groundnut, solution concentration, $\mathrm{P}$ uptake, root length.

1 Department of Soil Science and Agril Chemistry, Institute of Agricultural Science, BHU, Varanasi,221005, UP, India E-mail: amitavabhu@gmail.com

2 Department of Agricultural and Food Engineering, Indian Institute of Technology Kharagpur 721302 , India 


\section{IZVLEČEK}

\section{SPONTANA ARBUSKULARNA MIKORIZA JE POMEMBNA ZA OSKRBO RASTLIN ARAŠIDA (Arachis hypogea L.) S FOSFORJEM}

Proučevan je bil vpliv samonikle arbuskularna mikorize $(A M)$ na sprejem fosforja $(P)$ pri rastlinah arašida. Fungicid benomyl je bil uporabljen za zagotovitev kontrolnih rastlin brez mikorize. Gnojenje s P je potekalo na treh nivojih in sicer 0,50 in $400 \mathrm{mg} \mathrm{P}$ na $\mathrm{kg}$ tal, z oziroma brez uporabe benomyla. Arašidi so bili posajeni dva tedna po tretiranju tal s fungicidom, vzorce so jemali štirikrat tekom obdobja rasti. Pri vsakem jemanju vzorcev je bila določena teža poganjkov, koncentracija $P \vee$ poganjkih, dolžina korenin, topen $P \vee$ tleh in odstotek okužbe $z$ mikorizno glivo, na obeh nivojih tretiranja s fungicidom in na vseh nivojih dodatka P. Fungicid ni vplival na vsebnost topnega $\mathrm{P} \vee \mathrm{tleh}$. Ko je bil $\mathrm{P}$ omejujoč dejavnik je fungicid zmanjšal zgodnjo rast arašidov za 40 do $50 \%$ pri $\mathrm{P}-0$ in za 25 do $30 \%$ pri $\mathrm{P}-50$. Pri visokem dodatku $\mathrm{P}(\mathrm{P}-400)$ je imel fungicid majhen vpliv ali sploh ni imel vpliva na pridelek sušine. Tako kaže, da je fungicid vplival na rast rastlin $z$ vplivom na sprejem $P$ iz tal. Oskrba $s$ je vplivala na AM, ki je bila $40 \%$ pri koreninah skupine rastlin $\mathrm{P}-0$ in se je znižala na okoli $30 \%$ in $10 \%$ pri $\mathrm{P}-50$ in $\mathrm{P}-400$. Pri visokih odmerkih $P$ se je zmanjšal pomen $A M$ za oskrbo rastlin S P. Brez AM in pri nizkem nivoju $P$ je bil dotok $P \vee$ rastline samo $62 \%$ tistega, ki je bil pri rastlinah $z$ AM. AM je najpomembnejša za zagotovitev maksimalne rasti v začetku rastne sezone arašidov. Raziskava je pokazala da je AM značilno prispevala $z$ okoli $35 \%$ deležem oskrbe rastlin arašidov $s P$, da pa so lahko celo bolj pomembni tudi drugi vplivi, kot na primer, da izločki korenin prispevajo $k$ povečanju topnega $\mathrm{P} \vee$ tleh.

Ključne besede: Oxisol, benomyl, arbuskularna mikoriza, arašidi, koncentracija topnega $P$, privzem $\mathrm{P}$, dolžina korenin.

\section{INTRODUCTION}

In the tropics and subtropics (Oxislos and Alfisols) strong weathering is associated with an increase in the amount of sesquioxides, which exhibit high $\mathrm{P}$ sorption properties (Torrent, 1997). When P fertilizers are applied to replenish soil fertility major portion of is bound in oxisols by Fe/Al oxides as $\mathrm{P}$ compounds of variable adsorption strength, reducing the effectiveness of $\mathrm{P}$ fertilization and results in low $\mathrm{P}$ soil. Due to these reasons, phosphorus is often limiting crop growth in these soils of low P supplying capacity. Crop species differ in their ability to grow well in low phosphorus supplying soils (Föhse et al., 1988). A persistently low level of available phosphorus in the soil solution has led to numerous morphological, physiological, and biochemical adaptations by plants to survive in the nature. The results of field experiment on wheat, maize and groundnut (Bhadoria et al., 2001) carried out on a low $\mathrm{P}$ soil have shown that maize had an increased $\mathrm{P}$ influx during the middle growing season even though influx was very low in the early stage, groundnut showed a high $\mathrm{P}$ influx right from the beginning and wheat had an average to low $\mathrm{P}$ influx during the whole growing season. Possible reasons for this large variation of influx among the crops during the growing season at limiting $\mathrm{P}$ supply may have been due to the contribution of arbuscular mycorrhizae (AM) (Marschner, 1995), phosphatase activity near root (Elliott and Lauchli, 1986) and rate of root exudation (Gerke et al., 1994). The present investigation was undertaken to study the significance of AM on P influx of groundnut under field conditions. 


\section{MATERIALS AND METHODS}

Field experiments were carried out on a $\mathrm{P}$ fixing soil of eastern India at the Agricultural and Food Engineering Department experimental farm of Indian Institute of Technology Kharagpur, India. The soil with $\mathrm{pH}_{(\mathrm{H} 2 \mathrm{O})} 5.3$, organic $\mathrm{C} 3.5 \mathrm{~g} \mathrm{~kg}^{-1}$, contained $16 \%$ clay, $24 \%$ silt and $6.2 \mathrm{ppm} \mathrm{P}$ (Bray.1). Treatments consisted of three P levels, $\mathrm{P}-0$ (unfertilised, without $\mathrm{P}$ ), P-50 (50 mg P kg ${ }^{1}$ soil) and $\mathrm{P}-400$ (400 mg P kg${ }^{-1}$ soil) as single superphosphate and treatment with and without benomyl Treatments were arranged in a factorial randomised block design with four replication. Commercial formulated grades of the fungicides, benomyl was mixed thoroughly to $15 \mathrm{~cm}$ soil depth at $500 \mathrm{~kg} \mathrm{ha}^{-1}$. Nitrogen was applied at the rate of $20 \mathrm{~kg} \mathrm{ha}^{-1}$ and potassium at the rate of $50 \mathrm{~kg} \mathrm{ha}^{-1}$. Besides that $\mathrm{Ca}$ and $\mathrm{Mg}$ and micronutrients including $\mathrm{Zn}, \mathrm{Fe}, \mathrm{Cu}, \mathrm{B}, \mathrm{Mn}$ and $\mathrm{Mo}$ were applied at the recommended doses for this soil. After levelling the field plots, seeds of groundnut (cV. A K 12/24) were sown in rows keeping row to row spacing of $30 \mathrm{~cm}$ and plant to plant distance was $20 \mathrm{~cm}$.

The crop was harvested four times to obtain shoot yield, root length shoot $\mathrm{P}$ concentration, Soil solution P concentration (Adams, 1974) and per cent root infection by mycorrhizae during the growing season. Dry mass of shoots were recorded after drying in a hot air oven at $60^{\circ} \mathrm{C}$ to a constant weight and grinding to a fine powder. The $\mathrm{P}$ content was determined after tri-acid digestion, using the vanado-molybdophosphoric yellow color method Phosphorus influx is calculated as follows:

$$
\begin{aligned}
& \text { In }=2\left(\mathrm{U}_{2}-\mathrm{U}_{1}\right) /\left(\left(\mathrm{t}_{2}-\mathrm{t}_{1}\right)\left(R \mathrm{~L}_{2}+\mathrm{RL}_{1}\right)\right. \\
& \text { where, } \\
& \text { In }=\mathrm{P} \text { influx }\left(\mathrm{mol} \mathrm{cm}^{-1} \mathrm{~s}^{-1}\right), \\
& \mathrm{U}=\mathrm{P} \text { uptake }\left(\mathrm{mol} \mathrm{m}^{-2}\right), \\
& \mathrm{RL}=\text { root length }\left(\mathrm{cm} \mathrm{m}^{-2}\right), \\
& \mathrm{t}=\text { time (seconds) } \\
& \text { subscripts } 1 \text { and } 2 \text { refers to current and previous harvests }
\end{aligned}
$$

Percentage root infection:

Root infection was assessed on a representative root sample taken from each plot in fixed positions evenly distributed at each harvest to a depth of $15 \mathrm{~cm}$ were taken. The roots from each plot sample were separated, washed free of soil, cut into 1-1.5 cm lengths. Root samples were stained with tryptan blue (Philips and Hayman, 1970). AM infection of each plant was determined by estimating the percent root colonization as described by Bierman and Linderman (1981).

Per cent root infection was obtained as follows:

$$
\% \text { Root infection }=\frac{(100 \times \text { Number of intersections with arbuscular infections })}{\text { Total number of intersections counted }}
$$

\section{RESULTS}

\section{Soil solution concentration}

Table 1 shows the average soil solution concentration $\left(\mathrm{C}_{\mathrm{Li}}\right)$ during the growing season at different $\mathrm{P}$ fertilization both in benomyl treated and untreated plots. It may be seen that $\mathrm{C}_{\mathrm{Li}}$ increases exponentially with $\mathrm{P}$ fertilization. Application of fertilizer at the rate of $50 \mathrm{mg} \mathrm{P} \mathrm{kg}^{-1}$ soil had negligible effect on $\mathrm{C}_{\mathrm{Li}}$ which become significant only at P-400 level. Effect of benomyl on $\mathrm{C}_{\mathrm{Li}}$ was non significant (Table 1) at all harvests. In general, there was decrease in $\mathrm{C}_{\mathrm{Li}}$ in benomyl treated plots as compared to untreated plots and this was more at P-0 than at P-50 or P-400 levels.The results clearly show that benomyl had no major effect on $\mathrm{P}$ concentration in the soil solution, and consequently on the P availability in soil (Fitter and Nicholas, 1988). 
Bentivenga and Hetrick (1991) also found that benomyl application could not measurably change $\mathrm{P}$ availability in a silty clay loam soil.

Table 1. Effect of benomyl on soil solution concentration $(\mu \mathrm{M})$ of phosphorus of groundnut at no $\mathrm{P}$ (P-0), $50 \mathrm{mg} \mathrm{P} \mathrm{kg}^{-1}$ (P-50) and $400 \mathrm{mg} \mathrm{P} \mathrm{kg}^{-1}$ (P-400) application to the soil.

\begin{tabular}{|c|c|c|c|c|c|c|c|c|}
\hline P levels & \multicolumn{2}{|c|}{$30 \mathrm{DAS}$} & \multicolumn{2}{|c|}{$50 \mathrm{DAS}$} & \multicolumn{2}{|c|}{68 DAS } & \multicolumn{2}{|c|}{112 DAS } \\
\hline \multicolumn{9}{|c|}{ Benomyl } \\
\hline & - & + & - & + & - & + & - & + \\
\hline 0 & 0.90 & 0.62 & 0.85 & 0.52 & 0.73 & 0.45 & 0.71 & 0.45 \\
\hline 50 & 2.95 & 2.23 & 2.50 & 2.10 & 2.50 & 2.10 & 2.45 & 2.05 \\
\hline \multirow[t]{2}{*}{400} & 6.39 & 6.25 & 6.30 & 6.20 & 6.25 & 6.20 & 6.05 & 6.00 \\
\hline & SEm \pm & LSD( & & & & & & \\
\hline $\mathrm{P}$ & 1.21 & 3.7 & 1.18 & 3.49 & 1.13 & & 1.08 & 3.26 \\
\hline B & 1.06 & NS & 1.03 & NS & 3.41 & & 0.78 & NS \\
\hline PxB & 1.37 & NS & 1.33 & NS & 1.01 & NS & 1.18 & NS \\
\hline & & & & & 1.25 & NS & & \\
\hline
\end{tabular}

(P: Phosphorus levels; B: Benomyl application; DAS: Days after sowing; SEm: Standard error of mean; LSD: Least square difference)

\section{Root infection}

The root infection by AM as effected by benomyl and P supply is shown in Table 2 . In general the extent of mycorrhizal infection decreased, with increased application phosphate to the soil but the extent of this effect did not vary much between the crop species. It can be seen P supply affected percent root infected by AM, being $40 \%$ of the roots at P-0 and decreasing to around $30 \%$ and $10 \%$ at $\mathrm{P}-50$ and $\mathrm{P}-400$ respectively. This agrees with the results of earlier workers who have found that supply of phosphate to the plant by soil (Smith, 1982, Thompson et al., 1991) had an inhibitory effect on infection. High P application to the soil depressed AM formation and this effect has been attributed to the increase of P in the plant (Jasper, 1979, Amijee et al., 1989). There have been other experiment Mirinda et al., (1989) where it has been demonstrated that soil P levels have direct effect on AM particularly during the early stages of root colonization when the AM fungus is first developing in the soil. Benomyl was effective to suppress AM infection up to day 30. Thereafter some infection occurred, but was still less than in the untreated plot. Khaliq and Sanders (1997) found that inoculation of maize plants was effective during the early stages but response gradually disappeared during the later stages of growth. They also concluded that the inoculation response was reversed after the second harvest was because of higher root densities which might have been higher to render mycorrhizal fungus superfluous. Jakobsen (1987) and Thingstrup et al., (1998) reported that fumigation with Dazomet strongly decreased mycorrhiza formation and the effect persisted at least for 60 days after sowing. 
Table 2. Effect of benomyl on root infection (\%) of groundnut at no P (P-0), $50 \mathrm{mg}$ $\mathrm{P} \mathrm{kg}^{-1}$ (P-50) and $400 \mathrm{mg} \mathrm{P} \mathrm{kg}^{-1}$ (P-400) application to the soil.

\begin{tabular}{|c|c|c|c|c|c|c|c|c|}
\hline \multirow{3}{*}{$\begin{array}{c}\text { P levels } \\
\text { (mg kg-1 } \\
\text { soil) }\end{array}$} & \multicolumn{2}{|c|}{30 DAS } & \multicolumn{2}{|r|}{50 DAS } & \multicolumn{2}{|c|}{68 DAS } & \multicolumn{2}{|c|}{112 DAS } \\
\hline & \multicolumn{7}{|c|}{ Benomyl } & \\
\hline & - & + & - & + & - & + & - & + \\
\hline 0 & 60 & 0 & 32 & 8 & 28 & 10 & 25 & 12 \\
\hline 50 & 48 & 0 & 26 & 10 & 22 & 12 & 20 & 14 \\
\hline \multirow[t]{2}{*}{400} & 0 & 0 & 6 & 2 & 12 & 2 & 14 & 4 \\
\hline & \multicolumn{8}{|c|}{ Em LSD(0.05) } \\
\hline $\mathrm{P}$ & 1.46 & 4.42 & 1.30 & 3.91 & 1.48 & 4.47 & 1.30 & 3.91 \\
\hline B & 1.90 & 5.73 & 1.06 & 3.20 & 1.20 & 3.61 & 1.06 & 3.20 \\
\hline PxB & 2.07 & 6.24 & 1.84 & 5.65 & 2.09 & 6.28 & 1.84 & 5.64 \\
\hline
\end{tabular}

(P: Phosphorus levels; B:Benomyl application; DAS: Days after sowing; SEm: Standard error of mean; LSD: Least square difference)

\section{Shoot and root growth}

Table 3 gives the shoot growth as affected by $\mathrm{P}$ supply and Benomyl application. Phosphorus supply affected groundnut growth mainly in the later stages, early growth reduction was much smaller. Dry matter yield recorded following benomyl treatment was significantly lower over untreated plot. At high P supply (P-400), benomyl had little or no effect on dry matter production. This result indicates that benomyl has no direct effect on growth. This is in conformity with the findings of Carey et al. (1992) who concluded that Benomyl had no direct effect on the growth of wide range of plants. When $\mathrm{P}$ was limiting, the application of Benomyl did reduce early groundnut growth by $25 \%$ at P-0 and by $10 \%$ at P-50. In general, variation in dry matter production due to influence of both $\mathrm{P}$ levels and benomyl application has been small in the initial stage of crop growth but gradually increased up to third harvest. However the growth reduction during second harvest showed drastic decrease in benomyl treated P-0 plot than untreated plot. Groundnut had small growth rates when young, the rates increased strongly by 5-7 times in the middle for both benomyl treated and untreated plots. Reduction of growth following benomyl application is mainly attributed to eradication of AM and that might have influenced the P uptake from soil. Similarly Thingstrup et al., (1998) reported that the growth and $\mathrm{P}$ content of flux was lower in fumigated than in untreated plots and this effect decreases with increasing level of $\mathrm{P}$ application. 
Table 3. Effect of benomyl on shoot growth $\left(\mathrm{g} \mathrm{m}^{-2}\right)$ of groundnut at no P (P-0), 50 $\mathrm{mg} \mathrm{P} \mathrm{kg}{ }^{-1}$ (P-50) and $400 \mathrm{mg} \mathrm{P} \mathrm{kg}^{-1}$ (P-400) application to the soil.

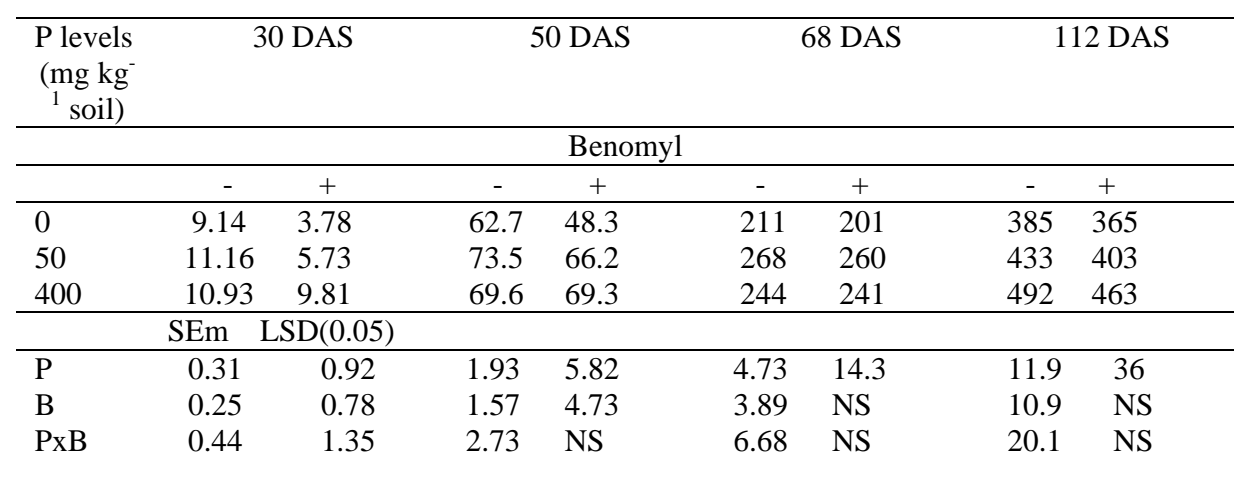

(P: Phosphorus levels; B: Benomyl application; DAS: Days after sowing; SEm: Standard error of mean; LSD: Least square difference)

Table 4. Effect of benomyl on root length $\left(\mathrm{km} \mathrm{m}^{-2}\right)$ of groundnut at no $\mathrm{P}(\mathrm{P}-0)$, 50 $\mathrm{mg} \mathrm{P} \mathrm{kg}{ }^{-1}$ (P-50) and $400 \mathrm{mg} \mathrm{P} \mathrm{kg}^{-1}$ (P-400) application to the soil.

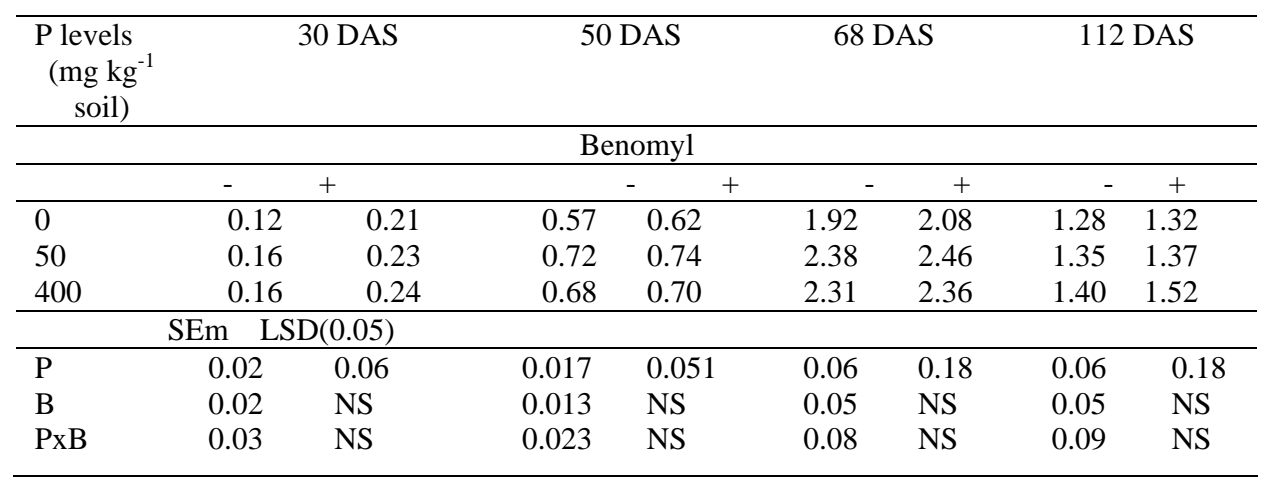

(P: Phosphorus levels; B: Benomyl application; DAS: Days after sowing; SEm: Standard error of mean; LSD: Least square difference)

\section{P Influx}

Benomyl application had almost no effect on $\mathrm{P}$ concentration in the shoot and so $\mathrm{P}$ uptake was closely related to dry matter production. The central question of this section is the effect of mycorrhiza on P uptake. If mycorrhizal hyphae absorb P and transport it to the root than the uptake expressed per unit of root and unit time, the influx, should be increased due to mycorrhiza. Figure 1 depict the relationship between the $\mathrm{P}$ influx as a function of the $\mathrm{P}$ concentration in soil solution. The $\mathrm{P}$ influx is shown for plants with full mycorrhizal infection or with no or reduced infection due to benomyl application. Furthermore is shown the $\mathrm{P}$ influx as calculated by the model which does not include mycorrhizal action nor the effect of root exudates on P solubility in soil, i.e., without chemical mobilization. 
30-50 DAS (a)

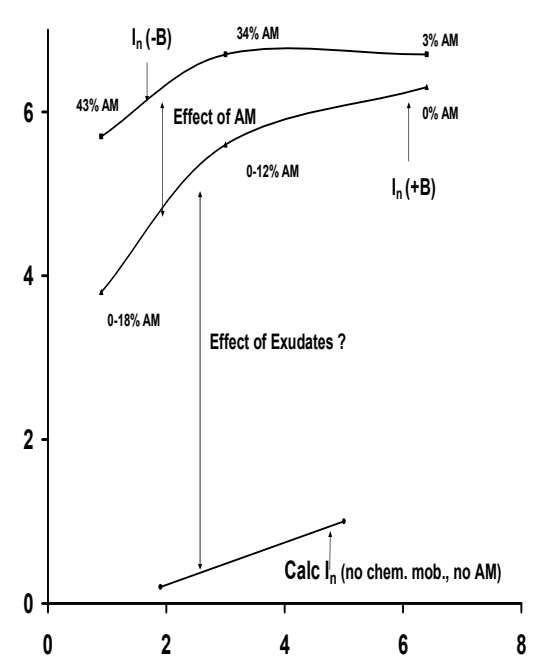

50-68 DAS (b)

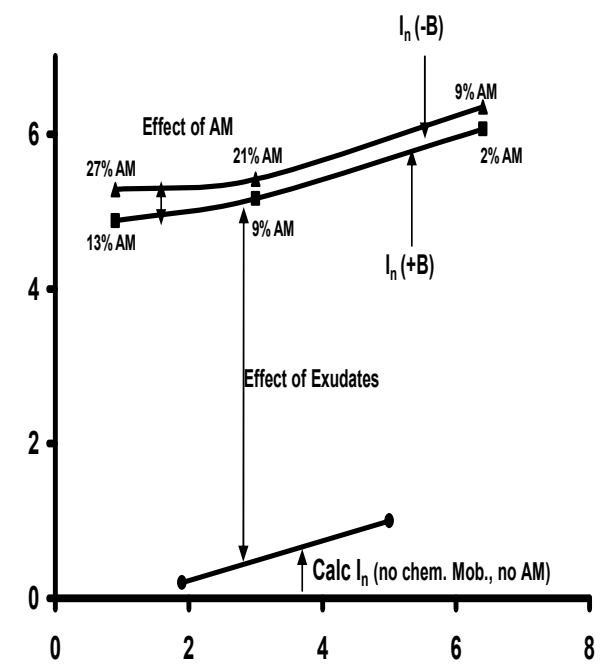

P soil solution conc., $\mu \mathrm{M}$

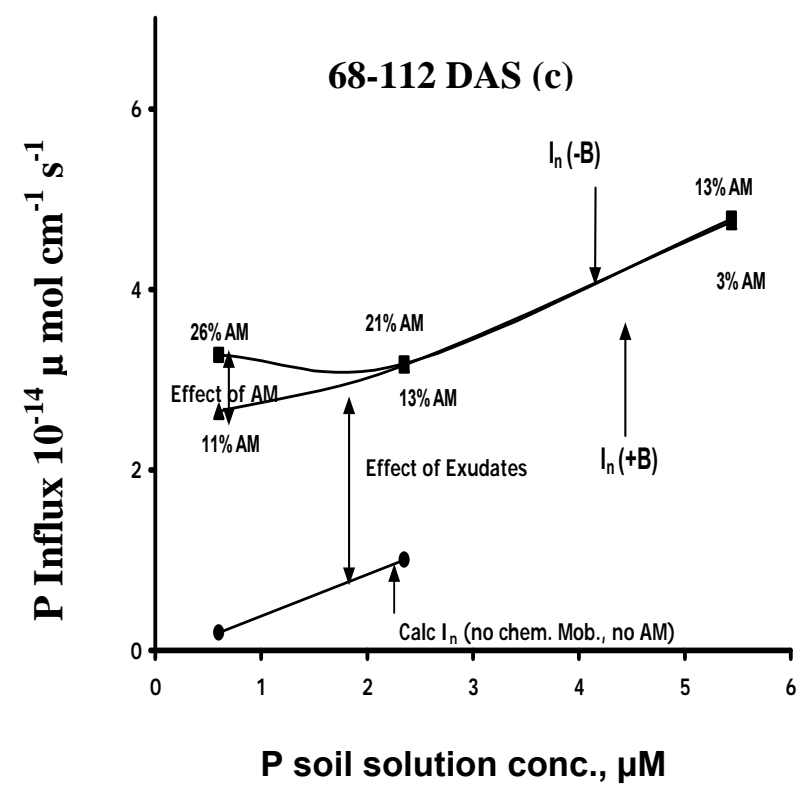

Figure 1:Phosphorus influx, $\left(\mathrm{I}_{\mathrm{n}}\right)$, of groundnut roots as a function of $\mathrm{P}$ concentration in soil solution of roots not treated $(-B)$ or treated with benomyl $(+B)$ in early (a) and middle (b) growing season. Furthermore the mycorrhizal infection (\% AM) of the roots is given and the $\mathrm{P}$ influx as calculated by a model without the action of arbuscular mycorrhiza nor of root exudates (DAS). 
The $\mathrm{P}$ influx in groundnut with full mycorrhizal infection or with no or reduced infection due to benomyl application shows that in the early growing season (Figure 1) the $P$ influx of groundnut was increased sharply and was not dependent on $P$ supply, being around $6 \times 10^{-14} \mathrm{~mol} \mathrm{~cm}^{-1} \mathrm{~s}^{-1}$ at $\mathrm{C}_{\mathrm{Li}}=0.8(\mathrm{P}-0)$ as well as at $\mathrm{C}_{\mathrm{Li}}=6.3 \mu \mathrm{M}$ (P-400). At this growth stage the effect of AM was largest at low P supply. Without $\mathrm{AM}$ infection and at low level the $\mathrm{P}$ influx was $67 \%$ of that with $\mathrm{AM}$ infection (Fig.1). In middle and end of the growth cycle, $\mathrm{P}$ influx was found to be related to $\mathrm{P}$ supply, where the degree of AM infection had no influence. Jakobsen (1986) and Smith (1982) reported two to three times increase in influx of P in to the roots of pea and clover plants respectively where mycorrhiza was not controlled. Influx of P in roots colonized by mycorrhizal fungi could be several times higher than in nonmycorrhizal roots (Smith and Read, 1997) in different crops.

\section{DISCUSSION}

Comparing the P influx of the plots treated with and without benomyl (Figure 1) it was observed that at full AM infection, P influx could increase by factor of 3 to 4 . However, without AM infection, the influx was still higher as calculated by simulation model. It is speculated that the reasons for measured influx being higher than calculated influx could be the solubilizing action of the root exudates.

According to the theory of diffusion $\mathrm{P}$ (Barber, 1995) transports to the root and therefore P influx should be about proportional to P concentration in soil solution, $\mathrm{C}_{\mathrm{Li}}$. This was evident in case of maize during early growing season, when influx was low, but at a later stage when P influx was high, soil solution concentration showed no effect on $\mathrm{P}$ influx and this could be the reason for different behavior of $\mathrm{P}$ influx in early and middle growing season. AM could not explain fully the variation in the measured $\mathrm{P}$ influx. A possible explanation, could be that in early growing season, the root functions mainly as an absorbing organ i.e., as sink for $\mathrm{P}$, and in that case transport to the root is determined by the concentration in soil solution. Later, the root actively participates in $\mathrm{P}$ dynamics in the rhizosphere by excreting root extudates that influenced P solubility in soil.

Since in our experiments we assessed the effect of AM on the P influx we can now estimate the effect of root exudates that solubilize strongly bound soil $\mathrm{P}$ on $\mathrm{P}$ influx by knowing the difference between measured P influx without AM and calculated influx simulated by the nutrient uptake model. One has to keep in mind that the estimate of the effect of root exudates is a residual of all other determinations and calculation and all errors if committed will accumulate here. With this caution, it can be seen that chemical mobilization (action of root exudates) for groundnut was almost $50-60 \%$ of $\mathrm{P}$ influx in early and middle of the season and becoming less in the later part of the growth stages. The remaining 50 to $40 \%$ of $\mathrm{P}$ influx not accounted for by model calculation or by AM, could be due to root exudates and other factors that solubilize strongly bound soil P. Root exudates, often as a reaction to phosphorus deficiency (Ae et al., 1990; Gerke et al., 1994;) could have made an important contribution towards $\mathrm{P}$ uptake, because of their influence on P solubility in soil. 
The results show that AM can make an significant contribution towards P nutrition as observed in groundnut, but other factors, like P solubilization by root exudates, can be even more important.

\section{ACKNOWLEDGEMENTS}

This study was financed by Volkswagen Foundation, Germany. The first author gratefully acknowledged Alexander von Humboldt Foundation for the award of fellowship for writing this publication.

\section{REFERENCES}

Adams, F. (1974): Soil solution; In The Plant Root and its Environment. Ed. E.W. pp. 441-481 Carson University Press of Virginia Charlottesville.

Ae, N., Arihara, J., Okada, K., Yoshihara, T., and Johansen, C. (1990): Phosphorus uptake by pigeon pea and its role in cropping systems of Indian subcontinent. Science, 248: 477-480.

Amijee, F., Tinker, P.B., Stribley, D.P. (1989): The development of endomycorrihizal systems. VII. A detailed study of the effects of soil phosphorus on colonization. New. Phyto., 111: 435-446.

Barber, S.A.(1995): Soil nutrient bio-availability-A mechanistic approach. $2^{\text {nd }}$ edition. Wiley New York.

Bentivenga., S. P., Hetrick, B. A. D. (1991) Relationship between mycorrhizal activity, burning, and plant productivity in tallgrass prairie. Can. J. Bot., 69: 2597-2602.

Bhadoria, P.B.S., Singh, S., Claassen, N. (2001): Phosphorus use efficiency of crop species grown on low phosphorus supplying soil. XIV International Plant Nutrition Conference, Hannover, Germany 27. July- 3rd. August 2001.

Bierman, B., Linderman, R. G. (1981) Quantifying vesicular-arbuscular mycorrhizae, a proposed method towards standardisation. New. Phyto., 87: 63-67.

Carey,P.D., Fitter, A.H., Watkinson, A.R. (1992): A field study using benomyl to investigate the effect of mycorrhizal fungi on plant fitness.Oceologia., 90: 550-555.

Claassen, N., Steringrobe, B. (1999): Mechanistic simulation models of nutrient uptake. In Mineral nutrition of crops, Fundamentals Mechanisms and Implications. Ed. Z .Rengel. pp. 327-367. Haworth Press, Inc., New York.

Elliott, G. C., Lauchli, A. (1986): Evaluation of acid phosphatase assay for detection of phosphorus deficiency in leaves of maize (Zea mays L). J. Plant. Nutr.,9:14691477.

Fitter, A. H., Nichols, R. (1988): The use of benomyl to control infection by vesicular-arbuscular mycorrhizal fungi. New. Phytol., 110: 201-206.

Foehse, D., Claassen, N., Jungk, A. (1988): Phosphorus efficiency of plants. I External and internal phosphorus requirements and phosphorus uptake efficiency of different plant species. Pl. Soil., 110: 101-109.

Gerke, J., Römer, W., Jungk, A. (1994): Excretion of citric and malic acid by proteoid roots of Lupinus albus: Effect on soil solution concentration of phosphate, iron and aluminium in the proteoid rhizosphere Oxisol and a Luvisol. Z. Pflanzenernähr. Bodenk., 157: 289-291. 
Jackobsen, I. (1986): Phosphorus inflow into roots of mycorrhizal and non mycorrhizal peas under field conditions. In Physiological and genetic aspects of Mycorrhiza, Eds. Gianinazzi-Pearson V. \& Gianinazzi S., 317-322. Paris, INRA.

Jasper, D.A., Robson, A.D., Abott, L.K.(1979): Phosphorus and the formation of vesiculararbuscular mycorrhizas. Soil. Biol. Biochem., 11: 501-506.

Jakobsen, I.(1987): Effect of VA mycorrhiza on yield and harvest index of field grown pea. Pl. Soil., 98: 407-415.

Jungk, A.(2001): Root hairs and the acquisition of plant nutrients from soil. J. Plant. Nutr. Soil Sci., 164:121-129

Jungk, A. (1974): Phosphate uptake characteristics of intact root systems in nutrient solution as affected by plant species age and P supply. In Proceedings of the $7^{\text {th }}$ International colloquium on plant analysis and fertilizer problems (J. Wehrmann). Ed. 519-527. Hannover, Germany.

Khaliq, A., Sanders, F. E. (1997): Effect of phosphorus application and vesicular arbuscular mycorrhizal inoculation on the growth and phosphorus nutrition of maize. J. Plant. Nutr., 20: 1607-1616.

Marschner, H. (1995) Mineral nutrition of higher plants Academic press. London UK.

Miller, M.H., McGonigle, T.P., and Addy, H.D.(1995): Functional ecology of vesicular arbuscular mycorrhizas as influenced by phosphate fertilization and tillage in an agricultural ecosystem. Crit. Rev. Biotech., 15: 241-255.

Miranda De, J.C.C., Harris, P.J., Wild, A.(1989): Effect of soil and plant phosphorus concentration on VAM in sorghum plants. New.Phytol., 112:405-410.

Nye, P.H., Mariott, F. C. H. (1969): A theoretical study of the distribution of substances around roots resulting from simultaneous diffusion and massflow. Pl. Soil., 30: 459-472.

Phillips, J.M., Haymann, D.S. (1970): Improved procedures for clearing roots and staining parasitic and vesicular-arbuscular fungi for rapid assessment of infections.Trans. Bri. Мусо. Soc.,55: 158.

Rovira, A.D. (1976): Studies on soil fumigation I. Effects of ammonium, nitrate and phosphate in soil and on the growth, nutrition and yield of wheat. Soil. Biol. Biochem.,8: 241247.

Smith, S.E. (1982): Inflow of P into mycorrhizal and non mycorrhizal plants of trifolium alexandrium at different levels of soil phosphate. New. Phytol., 90: 293-303.

Smith, S.E., Read, D.J.(1997): Mycorrhizal Symbiosis, Academic Press, San Diego.

Smith, S.E., Gianinazzi-Pearson, V. (1988): Physiological interactions between symbionts in vesicular-arbuscular mycorrhizal plants. Ann. Rev. Pl. Physio. Pl. Mo.l Bio., 39: 221-244.

Tennat, D. (1975): A test of modified line intercept method of estimating root length. J. Ecol., 63: 995-1001.

Thingstrup, I., Rubeak, G., Sibbensen, E., Jakobson, I. (1998): Flax depends on arbuscular mycorrhizal fungi for growth and P uptake at intermediate but not at high soil P levels. Pl. Soil., 293: 37-46.

Thompson, B.D., Robson, A.D., Abott, L.K.(1991): Soil mediated effects of phosphorus supply on the formation of mycorrhizas by scutellispora calospora (Nicol, \& Gerd., Walker \& Sanders) on subterranean clover. New. Phytol., 118: 463-469.

Torrent, J. (1997): Interaction between phosphate and iron oxide. Adv. Geoecol.,30: 321-344. 